\title{
Financial Health of Enterprises as a Tool of Business Potential of an Area
}

\author{
Petra Pártlová, ${ }^{*}$ \\ ${ }^{1}$ Institute of Technology and Business in České Budějovice, Faculty of Corporate Strategy, Okružní 517/10, České Budějovice \\ 37001, Czech Republic
}

\begin{abstract}
The paper discusses the evaluation of the financial stability of an enterprise, depending on the business potential of a municipality. The aim of the research is to prove a relation of the prediction models and their ability to predict the financial ability of an enterprise depending on sample clusters of the business potential in a municipality. In the first part of the research, the municipalities are clustered using the cluster analysis and the municipalities are classified into four clusters - economic, social, infrastructural, and environmental. Subsequently, financial data on business entities located in the area are used and the prediction models are calculated using the Czech indices of the Neumaiers. The results are further graphically evaluated in terms of size and sectors of the enterprise. The ANOVA method is verified to assess the independence of the creditworthiness models on sample clusters. Regarding the method and the analytical tool, it is possible to state their suitable choice; the outputs are relevant, valid, and usable in practice. The influence of the creditworthiness on the environmental cluster in the area is proved.
\end{abstract}

Keywords: IN Index, cluster, ANOVA method, creditworthiness

\section{Introduction}

The enterprises of proper financial health have been discussed by the researchers for several decades $[1 ; 2 ; 3 ; 4 ; 5]$. It is usually related to the enteprises showing growth in the number of employees, turnover, profitability, etc. Such enterprises are increasingly discussed in relation to the economy, and the authors focus on the factors affecting the financial stability of the enterprise and their contribution to the economy $[6 ; 7 ; 8 ; 9 ; 10 ; 11 ; 12 ; 13 ; 14]$. The factors influencing the prosperity of an enterprise, and thus their competitiveness is classified into endogenous: size, financial performance, capital structure, liquidity, flexibility in external financing, earnings stability, plan of financial results, audit quality, disclosure, corporate governance, ownership structure, investors' protection, corporate ethics, individual risks, or internal risks, etc. $[15 ; 16 ; 17 ; 18]$ and exogenous: risk free rate decrease, Financial market development, the GDP growth, bank lending to non-financial private sector growth, foreign direct investment growth, money supply growth, unemployment rate growth, the appreciation of domestic currency, politic stability, government expenditures growth, banking system liquidity, corporate tax rate growth, long-term interest rate growth, inflation growth, corruption growth, systematic risks or risks of external environment, etc. [19;20;21;22]. During an economic crisis, general attention is paid to the enterprises that show stable financial health, contributing to economic growth. At the same time, they play a key role in dealing with some important economic issues, such as reducing unemployment and creating jobs. The current discussion therefore focuses on factors contributing to a stable, competitive business environment in different countries [23; 24]. Research into the financial health of an enterprise is related to the research of the benefits of small and mediumsized enterprises. Many SMEs have good financial conditions, and such conditions contribute significantly to the creation of new jobs [25]. Blažek and Uhlír [26] even identify the SMEs as a key tool for regional development, addressing the unemployment issues, creating good conditions for the creation of innovations in order to reduce negative regional disparities. However, it should be mentioned that the population of small and medium-sized enterprises is rather heterogeneous, with the largest share of the start-ups disappearing within a few years of their establishment [27]. Another part of the enterprises, not nearly as numerous, is stagnant and does not expand significantly. The smallest part of newly established enterprises is growing rapidly, and such enterprises have the largest share in creating new employment [27]. Currently, there are two strong directions of regional development and the promotion of competitiveness: the regional innovation systems and the theory of global production networks. In such theories, the small and medium-sized enterprises play a special role and the specific ways of their cooperation and the agglomeration effects induced by them (economies of scale in conditions of intensive cooperation and created networks of specialized services together with highly flexible response to the changing demand). The small and medium-sized enterprises and their emerging clusters, together with supporting institutions, are therefore considered to be the most important subjects of economic development in the regions

\footnotetext{
* Corresponding author: partlova@mail.vstecb.cz
} 
as analysed. The benefit of this theory is to stimulate a comprehensive discussion about the interrelations between the competitiveness and socio-cultural environment of the regions and the regional rooting of the enterprises. In such relation, the positive influences are emphasized, especially for large enterprises in the networks of contacts, influencing the possibilities of further development of small and medium-sized enterprises in the respective region to a large extent. [28]. In this context, many regional economists see the regions as the intersection of spatial relations and networks of contacts, known as networking [26]. The location of the enterprise in the region seems to be a major factor that significantly affects the financial stability of the enterprise. Black and Henderson [29] argue that the enterprises located in agglomeration regions show the impact of positive externalities. Such positive externalities primarily mean knowledge transfer and the influence of municipal institutions. The enterprises in agglomeration areas also have better access to some specialized resources (such as educated workforce) [29]. Sleuwaegen, Goedhuy; Krasniqi; and Damborský and Wokoun [30; 31; 32] focus their research on the influence of geographical location on the location of small and medium-sized enterprises, and the proximity of sales markets has a positive effect on development and stability of the SMEs, even more in the services sector. Another important aspect is related to the location of medium-sized enterprises close to the suppliers. The dependence on competitors' proximity is found for the micro-enterprises. Regarding the secondary and tertiary enterprises, the authors discuss the availability of professional services and the overall economic growth of the region as important factors. In the Czech Republic, the SMEs play a crucial role, as small and medium-sized enterprises in the Czech economy make up the vast majority. In the long run, the representation of SMEs has been around 99\% [41], with them employing less than $60 \%$ of the total number of employees [42]. Based on such figures, it is deduced very clearly that the SMEs both contribute significantly to job creation, and they also have a major impact on the social and economic development of municipalities, cities, and regions, stimulate growing market dynamics and contribute to the stabilization of the economic system. The author of the paper focuses on a little-explored topic so far, in particular the influence of the financial health on the location of the enterprises in the relevant cluster of the examined region. The aim is to find out whether there are clusters (economic, social, infrastructural, and environmental) with a significant share of the enterprises.

\section{Methods}

The most important data sources were secondary data for most municipalities in the region of South Bohemia, provided by Ekotoxa. The data were focused on the description and evaluation of the state of the territory in four pillars (economic development and business activities, human resources, infrastructure and the environment). Four indicators were selected for the economic pillar, seven indicators for the social pillar, eleven indicators for the infrastructural pillar and seven indicators for the environmental. Emphasis was placed on the easy availability of data, their sufficient explanatory power and the possibility of updating. All the municipalities in the region of South Bohemia were included in the data collection, except for municipalities with more than 25,000 inhabitants.

For the calculation of the prediction models, related to the financial health of the enterprises not located in the territory of the tested municipalities, see the table. The data sample after generating the set from the Albertina database of Bisnode contained a total of 42,592 data rows. Each row contains the following: Enterprise identification: enterprise name, ID number, municipality region, municipality size, enterprise data: NACE, number of employees, NACE5A code, M_NACE, CZ-NACE5A, year of financial statements, financial statements for the year of operation of the enterprise: balance sheet, profit and loss statement, cash flow statement, sample indicators of profitability, activity, liquidity, indebtedness, productivity and more.

Subsequently, calculations, partial indicators, and items for the calculation of prediction models were carried out:

- EBIT / interest payable - the indicator compares EBIT with interest expense. The indicator shows how large such interest is in EBIT;

- Assets / Liabilities - this is an inverse indicator to the debt ratio (by default, the calculation is Liabilities / Assets or debts). The indicator says what part of all the assets (assets), and therefore all the resources (liabilities), is made up of external sources. In practice, therefore, it tells what level of risk and financial interest the owners bear;

- EBIT / Assets - profit, if it is not covered by money, is only a virtual quantity, as it is based on the current accounting principle. The indicator is thus an indicator of the degree of efficiency used by the total assets;

- Revenues / Assets - Revenues include both sales and other revenues (extraordinary). They do not relate purely to the main activity of the enterprise. The indicator is an alternative indicator of activity.

- Current assets / (short-term liabilities + Short-term bank loans) - this is a modified liquidity indicator;

- Overdue liabilities / income;

- Different weights V1-V6;

- $\quad$ MPO - based on the methods of the Neumaiers.!Neumaierová, 2002, 2005) 
Table 1. Number of enterprises in the region in 2017

\begin{tabular}{|l|l|l|}
\hline Year & Original data set & Adjusted data set \\
\hline 2017 & 9708 & 6983 \\
\hline
\end{tabular}

Source:Author

\section{Methods used}

- Regarding the analysis of financial health of the enterprise, the descriptive method is used. Pivot tables, line and other descriptive graphs are created.

Clustering of the municipalities uses the principle based on the creation of four models - the Economic Cluster, the Social Cluster, the Infrastructure Cluster, and the Environmental Cluster based on four groups of variables (economic, social, infrastructure and environmental area). According to such principle, a municipality is classified into a group according to its highest average ranking in the appropriate group (pillar). This means that the average ranking of the municipality in each pillar is calculated and then the group (the pillar with the best average ranking) is used.

The clusters (pillars) are analyzed by the Stepwise-backward-regression method in terms of its business potential. In order to analyze the business potential of rural areas in the clusters, the researcher identified it as a decisive index of the progressiveness of the economic structure, determining the socio-economic differentiation of the regions in the Czech Republic. Each cluster is analyzed by a stepwise method. The result is the finding of significant variables that significantly affect the business potential of each cluster [33].

- Regarding the comparison between the business potential of the area and the real economic state of the enterprises, the method of analysis of variance is used, which determines the significant dependence of profitable enterprises (financial health of the enterprises) on four models as created previously: economic cluster 1, social cluster 2, infrastructure cluster 3 and environmental cluster 4.

Analysis of variance (ANOVA) is a statistical method that allows the comparison of several means of independent random samples. The method was established by R.A. Fisher (1890-1962).

The aim of the ANOVA analysis is to prove that the values of the qualitative character of $\mathrm{X}$ affect the values of the quantitative character of $\mathrm{Y}$. That is, the creditworthiness of the enterprise affects the clusters. The values of the character $Y$, which belong to the value xi of the factor $X$, are denoted by yi1, yi2, ..., yini. The principle of the ANOVA method, which we prove the dependence of $Y$ on $X$, and the dependence of the clusters on the creditworthiness of the enterprise, is based on the fact that the total variability measured by the sum of the squares of deviations from the overall average, is divided into the variability within the selections and the variability between the selections.

It is assumed that there are $\mathrm{k}$ levels (values of $\mathrm{xi}$ ) of $\mathrm{X}$, with an effect on $\mathrm{Y}$, as expressed by the following relation: $\mu \mathrm{i}=\mu+\alpha \mathrm{i}, \mathrm{i}=1,2, \ldots, \mathrm{k}$,

and:

- $\mu \mathrm{i}$ is the mean of $\mathrm{Y}$ in the ith group (relevant to the value of xi factor),

- $\mu$ the total mean of $Y$,

- $\alpha \mathrm{i}$ is the effect of the value of xi factor on the character of $Y$.

Then, null hypothesis $\mathrm{H} 0$ is formulated, with all the selections coming from the same sample, and that the values of the factor $\mathrm{X}$ have no effect on the values of the character Y. Assuming that the values of $\alpha \mathrm{i}$ come from the same base set with zero mean $\mathrm{E}(\alpha \mathrm{i})$ and constant variance of $\sigma 2$.

$\mathrm{H} 0: \mathrm{E}(\alpha 1)=\mathrm{E}(\alpha 2)=\ldots=\mathrm{E}(\alpha \mathrm{k})=0$,

An alternative hypothesis is formulated to the contrary, as $\mathrm{H} 0$ will not apply, provided that at least two items, such as $\mathrm{i}$ and $\mathrm{j}$, apply:

$\mathrm{H} 1: \mathrm{E}(\alpha 1) \neq \mathrm{E}(\alpha 2)$.

If accepting $\mathrm{H} 0$, the independence of the values of $\mathrm{Y}$ on $\mathrm{X}$ is deduced, and $\mathrm{Y}$ factor does not depend on the $\mathrm{X}$ factor. Otherwise, if $\mathrm{HO}$ is rejected, $\mathrm{Y}$ depends on $\mathrm{X}$ and $\mathrm{X}$ affects $\mathrm{Y}$.

The following hypotheses are carried out in the research:

H1: Spatial differentiation, based on the analysis of four pillars (economic, social infrastructural and environmental), does not prove their conditionality on the financial health of the enterprise.

$\mathrm{H} 2$ : In one of the clusters of the area under research, there are an increased number of creditworthy enterprises compared to other clusters. 
H3: The ANOVA tool together with the cluster analysis is appropriate to find out the relations of the clusters to the financial health of the enterprises.

\section{Results}

Analysis of the financial health of an enterprise in the region of South Bohemian region by the size of the enterprise

As reported by figure 1 , the categories of the small enterprise, micro-enterprise and middle-sized enterprise are creditworthy in more than $40 \%$. The creditworthiness of large enterprises is approximately $33 \%$. The grey zone is mostly related to large enterprises (50\%), followed by middle-sized enterprises (34\%) and small enterprises (32\%); the microenterprises are the least common.

By the analysis of the IN 95 index, the most bankrupt enterprises are tracked in the group of micro-enterprises (35\%), followed by the medium-sized enterprises with $25 \%$, the small enterprises $(26 \%)$ and the large enterprises with $17 \%$.

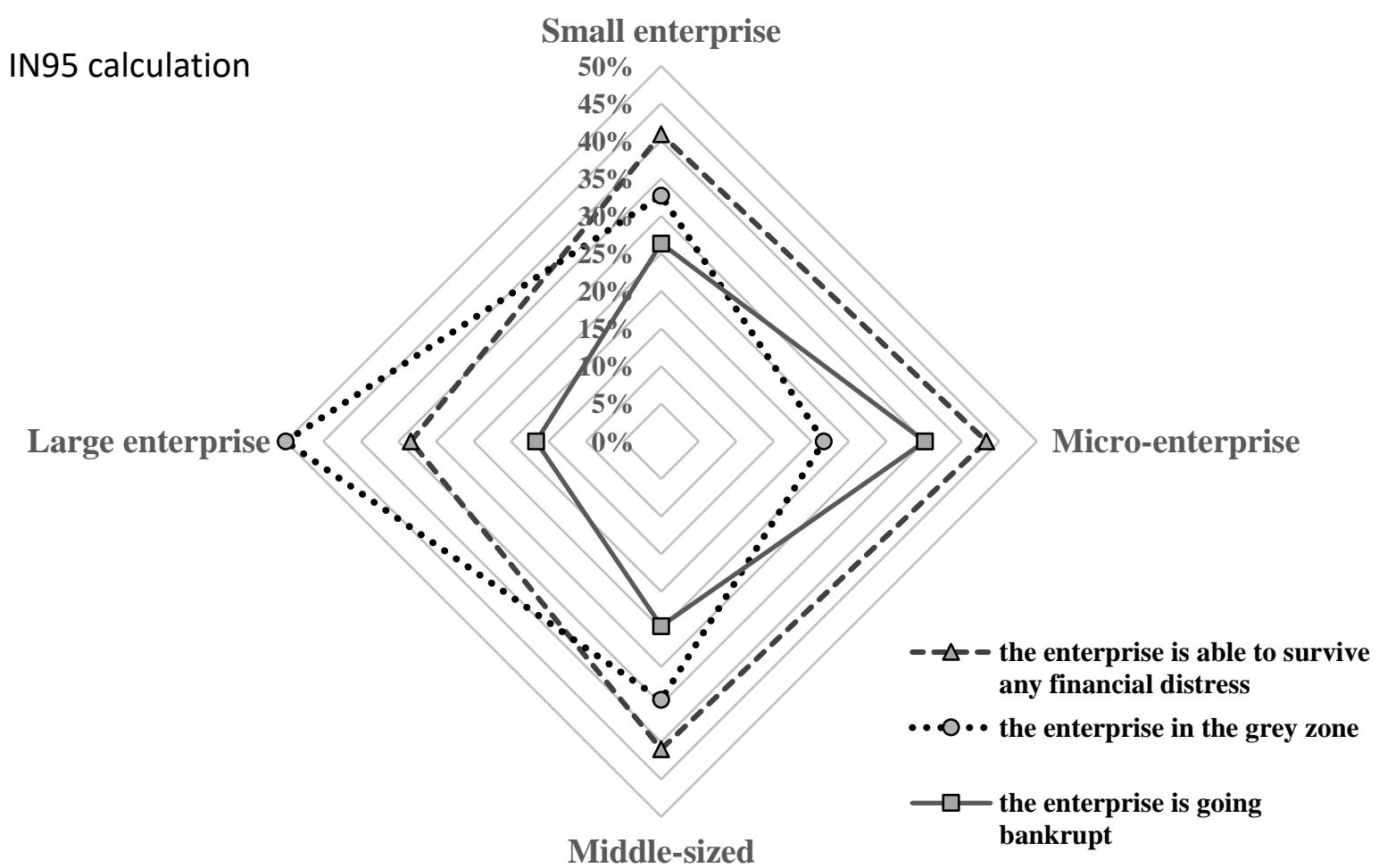

Figure 1. Financial health of South Bohemian enterprises by IN 95, in relation to the size of the enterprise

Source: Author

Relation of the financial health of the enterprises by NACE

The analysis of the impact of the financial health of the enterprises on the sector is performed. IN 95 is also used in the analysis

Regarding IN 95, the percentage share of A (agriculture, forestry and fishing) and C (manufacturing) sections worth mentioning as almost one third of the enterprises is either creditworthy, grey or bankruptcy zone. F section (construction) reports more than $40 \%$ of the enterprises as creditworthy, $20 \%$ in the grey zone and $35 \%$ in the bankruptcy zone. More than $50 \%$ of the creditworthy enterprises in in sections $\mathrm{G}$ (wholesale and retail trade; repair of motor vehicles and motorcycles) and $\mathrm{H}$ (transportation), see figure 2. 


\section{BY CZ-NACE}

Arts, entertainment and recreation Human health and social work activities Administrative and support service activities Professional, scientific and technical activities Real estate activities

Information and communication Accommodation and food service activities Transportation and storage Wholesale and retail trade; repair of motor. Construction

Water supply; sewerage, waste management. . Electricity, gas, steam and air conditioning.. Manufacturing Mining and quarrying Agriculture, forestry and fishing

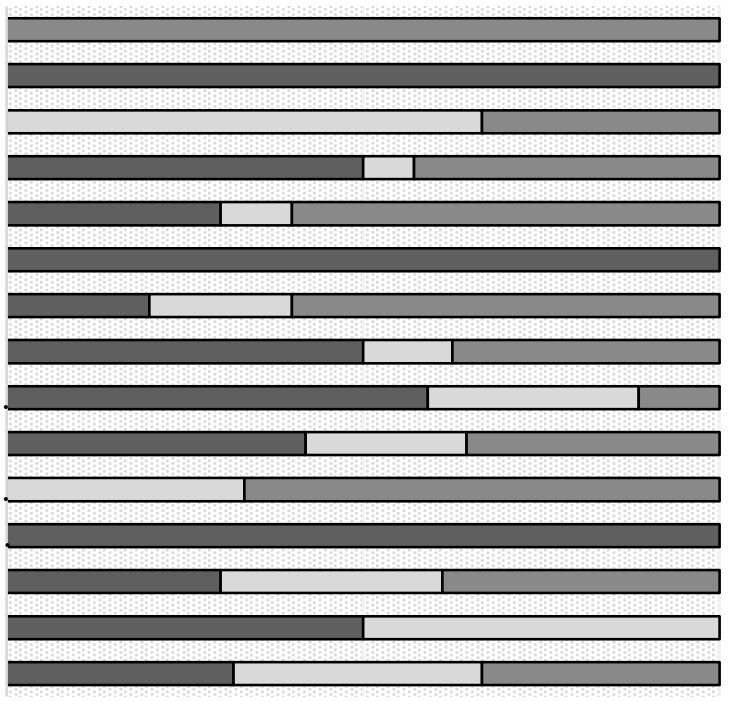
$0 \%$ $50 \%$

$\square$ the enterprise is able to survive any financial distress

$\square$ the enterprise in the grey zone

$\square$ the enterprise is going bankrupt

Figure 2. Financial health of South Bohemian enterprises by IN 95, in relation to CZ-NACE

Source: Author

\section{Relation of the financial health of the enterprises by the municipalities}

The enterprises of the region of South Bohemia and their financial health are also analysed in relation to the municipalities (type I, type II and type III, based on Act 128/2000 on Municipalities). Type III municipalities (municipality with extended powers) are not included in type II and I. Similarly, type II municipalities (municipality with authorized municipal office) are not included in type I.

By the analysis carried out through the IN95 index, it is identified that the largest number of enterprises in the region of South Bohemia are the creditworthy enterprises, both in municipalities I. II and III. This is followed by a group of the enterprises in the bankruptcy zone; very few enterprises are reported in the grey zone, according to the IN 95 analysis.

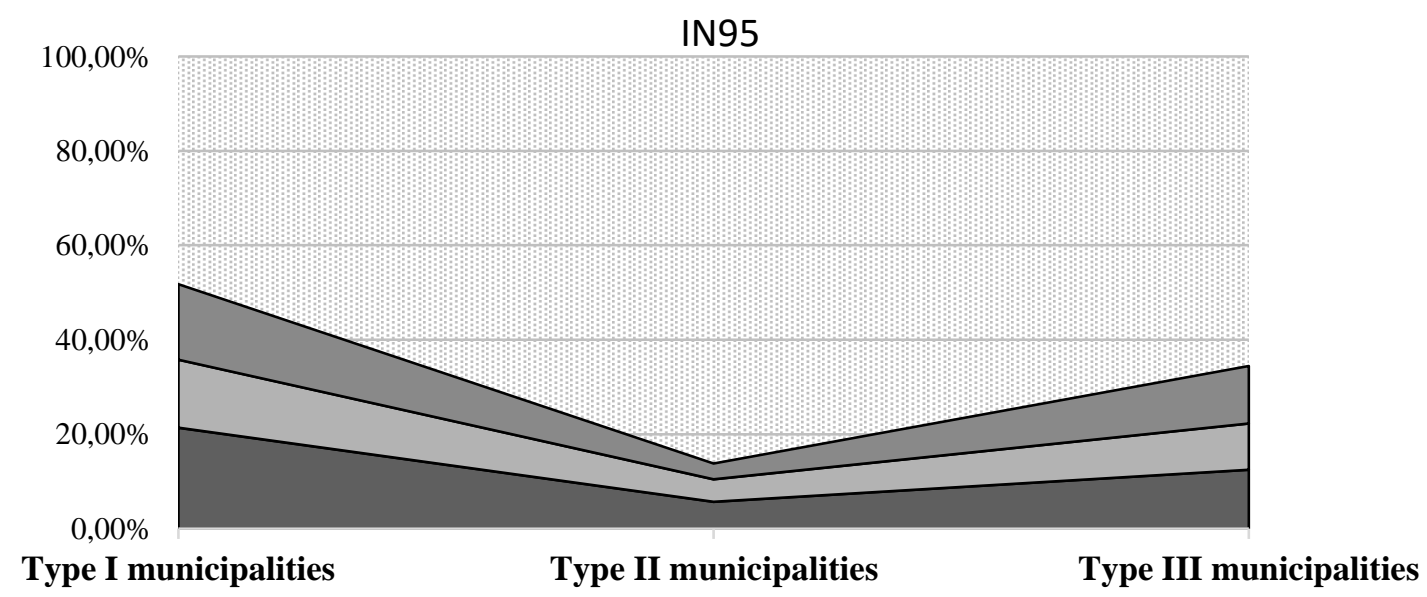

$\square$ the enterprise is going bankrupt

Figure 3. Financial health of South Bohemian enterprises by IN 95, in relation to municipalities Source: Author 


\section{Financial health of the enterprises in the region of South Bohemia, by IN 95}

The total comparison of the number of South Bohemian enterprises and their classification into different prediction zones revealed the following: by IN 95 analysis, it is reported that most of the enterprises are creditworthy, followed by the enterprises in the bankruptcy zone. A large number of the enterprises are included in the grey zone. On the other hand, the analysis of IN 01 and 05 shows the opposite trend, most of the enterprises are found to be the bankrupt or the grey zone, a smaller part of the enterprises in the region of South Bohemian is described as creditworthy.

\section{Relating the clusters to the health of the enterprises}

The health of the enterprises is measured by Neumeier index IN 95. The enterprises are divided by the sectors and size. Each group is analysed by ANOVA model with grouping variable corresponding to the category to which its location belongs to. The categories are computed above.

$$
I N 95=V(1) \cdot A+V(2) \cdot B+V(3) \cdot C+V(4) \cdot D+V(5) \cdot E-(6) \cdot F
$$

and:

$$
\begin{aligned}
& \mathrm{A}=\text { assets } / \text { debt } \\
& \mathrm{B}=\mathrm{EBIT} / \text { interest expense } \\
& \mathrm{C}=\mathrm{EBIT} / \text { total assets } \\
& \mathrm{D}=\text { sales } / \text { total assets } \\
& \mathrm{E}=\text { current assets } / \text { current liabilities } \\
& \mathrm{F}=\text { overdue } / \text { sales }
\end{aligned}
$$

\begin{tabular}{|c|c|c|c|c|c|c|}
\hline \multicolumn{7}{|l|}{ IN 95} \\
\hline \multirow{4}{*}{ ANOVA $\rightarrow$} & "" & "DF" & "SumOfSq" & "MeanSq" & "FRatio" & "PValue" \\
\hline & "Model" & 3 & 76.5344 & 25.5115 & 2.4213 & 0.0649 \\
\hline & "Error" & 653 & 6880.2151 & 10.5363 & "" & "'" \\
\hline & "Total" & 656 & 6956.7495 & "" & "" & "'" \\
\hline \multirow{5}{*}{ CellMeans $\rightarrow$} & "All" & 1.7039 & & & & \\
\hline & Model[1] & 1.4184 & & & & \\
\hline & Model[2] & 1.2770 & & & & \\
\hline & Model[3] & 1.7025 & & & & \\
\hline & Model[4] & 2.5692 & & & & \\
\hline PostTests $\rightarrow$ & $\multicolumn{2}{|c|}{"$ Model" $\rightarrow$ Tukey $\quad\{" '\}}\}$ & & & & \\
\hline
\end{tabular}

Table 2. Relating the clusters to the health of the enterprise according to index 95

Source: Author

The resulting table 2, see below, it is clear, that after the analysis of the index 95, the creditworthiness of the enterprises is reported to be category 4, and the environmental cluster is significantly higher than in other categories, i.e., the economic, the social and the infrastructural clusters. No model identified this difference at the 5\% significance level. For all of them, the level of significance is about $6.5 \%$, i.e., the error of the first kind (that is, the probability of a misidentified model is $6.5 \%$ ). However, due to the consistency and systematic nature of such three indices, it is assumed that the creditworthiness in the 4th category (environmental cluster) is significantly higher than the creditworthiness of the remaining clusters. Similar analyzes with the same result are also carried out regarding the other Neumaier indices IN 01 and 05 .

It is also interesting to determine the frequency of the creditworthy enterprises in the clusters, regardless of what point value was calculated for the indices in the range of creditworthy enterprises, figure 4 . The analyzed values for 2017 , for example for IN 95, ranged from 1.6 to 17.6 points (see the formula for IN 95). Subsequently, all creditworthy enterprises are included in the map of the municipalities according to the clusters. Map 1 shows that most creditworthy enterprises 
in the area are in cluster 3, with 176 enterprises, followed by a cluster of economically with 37 enterprises, then environmental cluster with 25 enterprises and social cluster with 21 enterprises, as calculated by IN95.

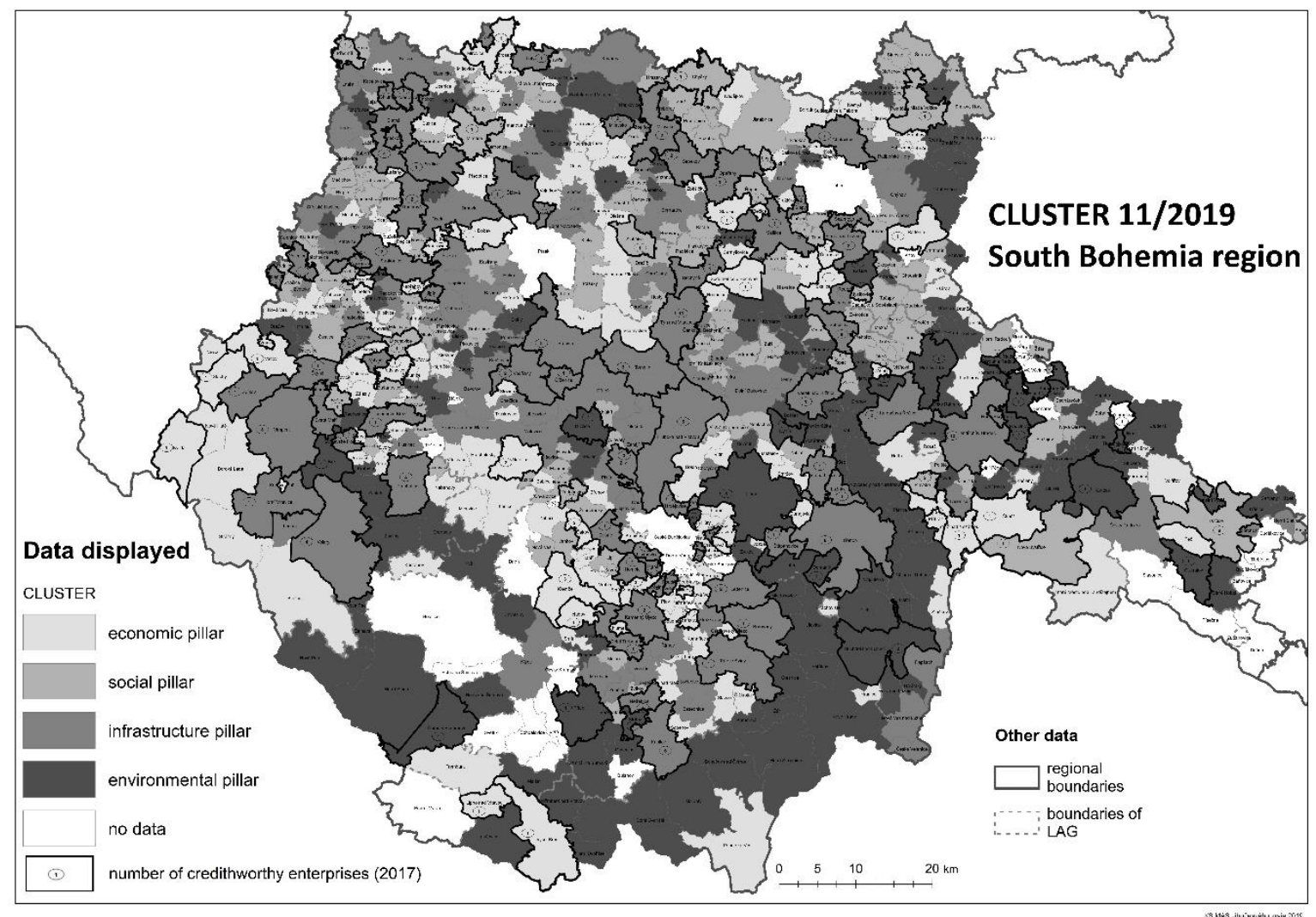

Figure 4. Location of the creditworthy enterprises in the clusters Source: Author

\section{Suggestions and recommendations}

Before the research, several hypotheses were established. The first consisted in the design of an economic model that would allow the determination of the economic potential of the municipalities; the second question was focused on finding and verifying suitable analytical methods for the model. A partial goal was the actual outputs of research, especially in terms of the usability of financial health indices of the enterprises in relation to the business potential of the municipalities. The following summaries and recommendations discuss the fulfilment of the above-mentioned objectives.

The structure of the pillars, including 29 indicators, reflecting the specifics of the regions in the Czech Republic, is considered appropriately designed. However, its final extent should be determined only after wide application, within all the regions in the Czech Republic. However, based on the example of the South Bohemian region, their number proved to be sufficient. Looking ahead, there is a need to precisely define the procedure for collecting relevant secondary and primary data, to specify the minimum scope of the observed period, to define the qualitative aspect of the database and the form of their processing before using it for the analysis.

The analytical tool Cluster Analysis proved to be suitable. Using the cluster analysis of municipalities (Clustering municipalities), four clusters of municipalities were created - economic, social, infrastructural and environmental, according to four groups of variables (economic, social, infrastructure and environmental environment), so that in each cluster, there were the municipalities that excel most in the area. Each municipality was included in a specific cluster according to which group (pillars) the municipality had the highest average ranking. This procedure brought the expected outputs and the structuring of municipalities.

An integral part, in accordance with the above scientific approach, is the analysis of the potential of rural municipalities in relation to the financial health of the enterprises. Here, the use of the ANOVA method proved to be suitable, which proved the relation to one of the clusters.

The potential of municipalities is an integral part of the total potential of the territory; however, it is not a sum, but an intersection of economic and financial indicators monitoring the financial health of the business sector in the territory. The method is based on four pillars (economic, infrastructural, social and environmental), similarly to the first procedure. Based on the cluster analysis, it is then possible to define a summary map of the potential of municipalities for the selected territorial unit with subsequent prediction of the business potential in the given municipality. In the region of South Bohemia, the calculation is based on three monitored indices of the Neumaiers (IN 95, IN 01, IN 05); the paper presents 
the results only for the IN 95 index) showing that the largest business potential, analyzed for the creditworthy enterprises, with good financial health, is traced to the municipalities of the environmental pillar, which corresponds to the character of the region.

The influence of the financial health of the enterprises in the research was also evaluated from the point of view of sectoral differentiation and size categorization. The results cannot be considered as generally valid and final, yet they are believed to have scientific value. In accordance with the results and findings, the following action is recommended:

- Research into different components of the business environment should continue to ensure the collection of input data from business entities in times of economic recession when other results of the financial health of the business sector in the addressed regions of the Czech Republic can be predicted.

- The follow-up research should be focused on the sub-sectors, from the point of view of sectoral and size differentiation of business entities and find out their influence on the created clusters of municipalities and their potential.

Regarding practical outputs focused on the local and regional development of the Czech Republic, it is possible:

- Create a guidebook for municipal self-government, including recommendations on how and with what tools of the external and internal environment to increase the business potential of the municipality. Such tools include, in general, the creation of an area-based local development strategy for well-defined sub-regional rural areas with a specific business sector, the creation of public-private partnerships at local level, the multi-sectoral design and implementation of a strategy based on the synergies between business actors from different sectors of the local economy, the application of innovative practices, the creation of clusters of local and regional partnerships.

\section{Conclusion}

Many research institutes, both in the Czech Republic and abroad, address the issue of stabilization and development of the business environment, especially in rural areas. The solution proves to be a limiting factor in ensuring the functionality of the small and medium-sized enterprises in the area, which is a crucial socio-economic accelerator and stabilizer for the countryside. However, a prerequisite for a successful solution for the development of business activities is knowledge of business potential, including good creditworthiness indicators and characteristics of local business entities.

Lundström a Stevenson [34] carry out an extensive research of SMEs, regarding their economic potential in the region, and its development. In particular, they analyse the economic and financial indicators, identified as crucial for the existence and development of the SMEs. Their research activities and the outputs show that the enterprises showing good financial health, and conversely, the enterprises in danger of extinction (bankruptcy), are the key entities in terms of the dynamics of development of the region in which such enterprises carry out their activities.

Similar conclusions are revealed by Parsley and Dreessen [35], also showing the crucial importance of stable and progrowth SMEs in the context of regional development. They also consider the enterprises that are of good financial health and that are an important source of employment and well-being in the area where they operate to be the pro-growth and stabilizing part of the region. In their conclusions, they similarly state the importance of the enterprises with a pro-growth character, emphasizing the need to know their development limits, business potential, and also the conditions of their stability and development. They identify the knowledge of such pro-growth parameters as a basic precondition for a more efficient and effective setting of the state support. Hill [36] adds that various forms of business support significantly affect the potential and limits of the development at the local and regional level. Shucksmith et al. [37] in their study point to the need for targeted financial and non-financial support to the growth-oriented enterprises in the region. They also notice that the financial support and the subsidy should be oriented both to pro-growth companies, and to those that are located in pro-growth regions, and in the municipalities if there is a prospect of better development conditions.

Similarly, Pělucha [38] carries out the research, the aim of which is to demonstrate the targeting of financial support to the municipalities with a better socio-economic level of development in the context of supporting the dynamics of territorial cohesion. From its results, a statistically significant relation between the subsidies provided for non-agricultural activities and the socio-economic level of the supported municipalities is not fully demonstrated. In terms of the intensity of the subsidy provided, however, rather peripheral and structurally weak municipalities are the most supported. The author adds that the financial share of total public expenditure is marginal compared to the group of agricultural instruments. The research results throughout the Czech Republic show that the current financial subsidies in the agricultural sector is focused exclusively on the transformation of the agricultural enterprises in order to support both their production function and non-productive, environmental function, which is gradually disappearing from the rural area nowadays.

It is a fact that such targeted subsidies contribute, both in extensive areas and especially in high-production areas, to a departure from their original role as mere producers, and a new role for landscape maintenance (sometimes called 
landscape managers) is emerging. Pělucha $(2006$, p. 166) further notes that "such new role mostly works to prevent the creation of self-sufficient business entities that could function in the future without any support from public sources." The author's dissertation (Possibilities of Diversification of Agricultural Enterprises in the LFA of the Bohemian Forest) also focuses on this issue isadvantaged areas. In the work, the author also addressed the process of designing a multifunctional management system, specified individual business activities in terms of their effectiveness on the economic results of agricultural businesses. She deals with the definition of production and non-production functions in the rural landscape and at the same time. she discusses the issue of objective setting of the financial instruments for the enterprises operating in naturally disadvantaged areas. In her work, the author also addresses the process of designing a multifunctional management system, specified business activities in terms of their effectiveness on the economic results of the agricultural enterprises. The thesis also includes the case studies focused on the calculation of economic efficiency of agricultural enterprises operating in the conditions of the border region of the Bohemian Forest with and without subsidies from the EU. The author draws similar conclusions as Pělucha. Without targeted subsidies, it is not possible to ensure the functionality of non-productive functions in the landscape. The crucial importance of landscape managers, who are mainly private farmers with a permanent residence in the place of their business, is confirmed. The farmers who bought land for the purpose of allocating subsidies from the EU are not such landscape managers, with few exceptions, they rather contribute to the degradation of the landscape. In conclusion, the author states that from the point of view of future generations and the preservation of the rural landscape, it is necessary and essential for these generations to maintain agricultural and non-agricultural activities in harmony. These conclusions, as reached more than 15 years ago, are followed by the author in this publication, and in the issues presented. The new theoretical definition of rural space in the systemic anthropo-ecological concept fully respects this.

The follow-up construction of the model of the total economic potential, and its four sub-areas (economic, infrastructural, social and environmental) implement such principle methodically into the working experience. The verification of the proposed methodologies on a regional scale and in more than 600 municipalities with valid and practically usable results indicates the correctness of the procedure. At the methodological level, the publication defines the procedure of aggregation of four sub-models into one final indicator; the calculations of four sub-models with commenting on the outputs from the solution are presented. In the next phase of the solution, the integrated model of economic potential is supposed to be verified at the regional level.

In terms of the importance of the relations between the financial health of the enterprises in the area and the structural representation of the pillars, such relationship is clearly demonstrated. The performed analysis revealed a strong relation between the financial health of the enterprises and the environmental parameters of the area where the enterprises work.

It is proved that the enterprises show better economic results in areas where the environmental aspect is emphasized, and the surroundings are not severely degraded. The data (Figure 4) also show that the degrading trend might be caused both by pumping over the natural potential of the territory and by not using it, and both of these extreme limits have a devastating effect on the economic potential of the territory. It can therefore be concluded that if this dependence was confirmed in other regions as well, this would be an important finding in the context of a new direction of regional policy and more effective targeting of financial and non-financial instruments.

In fact, a comprehensive review of the literature shows that that the research with a similar focus has been carried out yet neither in the Czech Republic nor abroad. On the one hand, this naturally limits the possibility of comparison with the outputs of other research organizations, but at the same time the solution contains a charge of new scientific knowledge and new research findings.

\section{References}

1. E. B. Deakin. A Discriminant Analysis of Predictors of Business Failure. Journal of Accounting Research. 10(1), 167179 (1972)

2. E. I. Altman, R. G. Haldeman, R. G., P. Analysis. A new model to identify bankruptcy risk of corporations. Journal of Banking and Finance. 1, 22-54 (1977)

3. M. E. Zmijewski. Methodological issues related to the estimation of financial distress prediction models. Journal of Accounting Research. 22, 59-82 (1984)

4. T. Shumway. Forecasting Bankruptcy More Accurately: A Simple Hazard Model. Journal of Business. 74(1), 101-24 (2001)

5. Y. J. Wang, H. S. Lee. A clustering method to identify representative financial ratios. Information Sciences. 178, 1087-1097 (2008)

6. M. Henrekson, D. Johansson. Gazelles as job creators: a survey and interpretation of the evidence. Small Business Economics. 35(2), 227-244 (2010)

7. C. Brush, D. Ceru, R. Blackburn. Pathways to entrepreneurial growth: The influence of management, marketing, and money. Business Horizons. 52(5), 481-491 (2009) 
8. O. Bajo-Rubio et al. Foreign Direct Investment and Regional Growth: An Analysis of the Spanish Case. Regional Studies. 44(3), 373-382 (2010)

9. J. Bradley. Stimulating Sustainable Growth Using Cohesion Policy: Realistic or a Holy Grail? International Evaluation Conference, Cohesion Policy 2014-2020: Towards Evidence-Based Programming and Evaluation. Vilnius. (2013)

10. J. Kaczmarek. Construction elements of bankruptcy prediction models in multi-dimensional Early Warning Systems. Polish Journal of Management Studies. 5, 130-143 (2012)

11. J. Du, Y. Temouri. High-growth firms and productivity: evidence from the UK. In Small Business Economy. 44, 123143 (2015)

12. M. Karas, M. Režňáková. Building A Bankruptcy Prediction Model: Could Information About Past Development Increase Model Accuracy? Polish Journal of Management Studies. 17(1), 116-130 (2018)

13. M. Kovacova, T. Kliestik, P. Kubala, K. Valaskova, M. Radišić, J. Borocki. Bankruptcy Models: Verifying Their Validity As A Predictor Of Corporate Failure. Polish Journal of Management Studies. 18(1), 167-179 (2018)

14. J. Belás, Z. Strnad, B. Gavurová, M. Čepel. Business environment quality factors research-SME management's platform. K.utb.cz [online]. Available at: https://publikace.k.utb.cz/handle/10563/1009535. (2019)

15. W. R. Nelson, R. Perli. Selected indicators of fiacnial stability. In: 4th joint central bank research conference on risk measuremtn and systemic risk. Frnakfurt am Main: ECB, 1-30 (2005)

16. C. S. Armstrong, J. E. Core, D. J. Taylor, R. E. Verreccia. When does information asymmetry affect the cost of capital? Journal of accounting research. 49(1), 1-40 (2011)

17. O. Barron, X. Sheng, M. Thevenot. Information enviroment and the cost of capital: a new approach, Working papers 2012-12, American University, pp 1-35 (2012)

18. L. Kotek, A. Nosek, A. Fiala, V. Bartos. Risks in industrial management systems. MM Science Journal. 12, 16081612 (2016)

19. W. A. Allen, G. Wood. Defining and achieving financial stability. Journal of Financial Stability. 2, 152-172 (2006)

20. European Commision. Approaches for assessing the impacts of the Rural Development Programmes in the context of multiple intervening factors, Findings of a Thematic Working Group established and coordinated by The European Evaluation Network for Rural Development. [online]. Available at: https://enrd.ec.europa.eu/sites/default/files/eb43a527-c292-f36c-fc51-9ea5b47cedae.pdf (2010)

21. T. C. Artiach, P. M: Clarkson. Disclosure, conservatism and the cost of equity capital: a review of the foundation literature. Journal Accounting and Finance. 51, 2-49 (2011)

22. V. Kubíčkova et al. Dynamické podniky služieb - gazely. Praha: Wolters Kluwer s.r.o., 152 (2016)

23. OECD. Rural - Urban Partnerships: An integrated approach to economic development. OECD Rural Policy Reviews. ISBN 978-92-64-20481-2 (2013)

24. J. R. Baldwin, D. Beckstead, W. M. Brown, D. L. Rigby. Agglomeration and the Geography of Localization Economies in Canada. Regional Studies. 42, 117-132 (2008)

25. D. L. Birch. Job Creation in America. In: J. Blažek, D. Uhlíř: Teorie regionálního rozvoje: nástin, kritika, implikace. Praha: Univerzita Karlova (2011)

26. J. Blažek, D. Uhlír. Teorie regionálního rozvoje: nástin, kritika, implikace. Praha: Univerzita Karlova (2011)

27. J. Brüderl, P. Preisendörfer. Fast-growing Businesses: Empirical Evidence from a German Study. International Journal of Sociology. 30(3), 45-70 (2000)

28. T. Mori, K. Nishikimi, E. T. Smith. The Number-Average Size Rule: A New Empirical Relationship Between Industrial Location and City Size. Journal of Regional Science. 48(1), 165-211 (2008)

29. D. Black, V. Henderson. A theory of urban growth. Journal of Political Economy. 107(2), $252-284$ (1999)

30. L. Sleuwaegen, M. Goedhuys. Growth of firms in developing countries: Evidence from Cote d'Ivoire. Journal of Development Economics. 68, 117-135 (2002)

31. B. A. Krasniqi. Building an Expanded Small Firm Growth Model in Transitional Economy: Evidence on Fast Growing Firms. Journal of East-West Business. 18(3), 231-271 (2012)

32. M. Damborský, R. Wokoun. Lokalizační faktory malého a středního podnikání v podmínkách ekonomiky ČR. Ekonomie a management. 2, 32-43 (2010) 
33. R. Christensen. Plane Answers to Complex Questions: The Theory of Linear Models, Third Edition. Springer-Verlag, New York (2002)

34. A. Lundström, L. A. Stevenson. Entrepreneurship Policy. Theory and Practice. New York: Springer, 2005, ISBN 0387-24140-X (2005)

35. C. Parsley, E. Dreessen. Growth Firm Project: Key Findings, Industry Canada, 2004, [online]. Available at: https://www.ic.gc.ca/eic/site/061.nsf/vwapj/GrowthFirmsProject_KeyFindings_Eng.pdf/\$file/GrowthFirmsProject_ KeyFindings_Eng.pdf (2012)

36. B. Hill. Understanding the Common Agricultural Policy, Velká Británie: Taylor \& Francis Ltd. ISBN 978-1-84407777-9 (2012)

37. M. Shucksmith, D. L. Brown, S. Shortall, J. Vergunst, M. E. Warner. Rural transformations and rural policies in the US and UK. Hoboken: Taylor\& Francis. ISBN: 9781136502743 (2012)

38. M. Pělucha. Rozvoj venkova v programovacím období 2007-2013 v kontextu reforem SZP EU. 1. vyd. Praha: IREAS, ISBN 80-86684-42-3 (2006)

39. Neumaierová, I., 2002. Výkonnost a tržní hodnota firmy: metody, ukazatele, využití v praxi, 1.vyd. Praha: Grada, 215. ISBN 80-247-0125-1

40. Neumaierová, I., 2005. Neumaier Ivan Index IN05: Index IN05. In Evropské finanční systémy: Sborník př́spěvků z mezinárodní vědecké konference. Brno: Masarykova univerzita v Brně, 143-146

41. V. Koráb, P. Koudelková. What determines innovation in small and medium enteprises? A case study from the Czech Republic. Transformations in Business and Economics. 15. 78-88 (2016)

42. Ministry of Industry and Trade. MIT. Report on SME development and their support (Zpráva o vývoji malého a středního podnikání a jeho podpoře). Available at https://www.mpo.cz/cz/podnikani/male-a-stredni-podnikani/studiea-strategickedokumenty/zprava-o-vyvoji-maleho-a-stredniho-podnikani-a-jeho-podpore-v-roce2016--232792/

(2017) 